Ewa Miśkowiec

ORCID: 000-0003-2530-3393

Akademia Ignatianum w Krakowie

\title{
Szkoła przestrzeniq wdrażania ucznia do samowychowania
}

\author{
The School as a Student Implementation Space
}

for Self-Upbringing

\begin{abstract}
ABSTRAKT
W procesie samowychowania wychowanek, stajac się dla siebie wychowawcq, podejmuje wysiłek stawania się sobq poprzez wybór konkretnej, własnej drogi życiowej, podejmowanie samodzielnych decyzii i przyjmowanie za niq odpowiedzialności oraz poprzez kształtowanie poczucia własnej wartości, poznania siebie, akceptowania, formowania ideału własnej osoby $\mathrm{i}$ jego realizowania. Działania te nie pojawiaja się w aktywności wychowanka samoczynnie. Etap wdrażania do samowychowania przypada na średni wiek szkolny, co oznacza, że szkoła jest ta przestrzeniq, w której należy poszukiwać działań wdrażajqcych do procesu samowychowania. Ciqgle niedostatecznie opisane czynniki środowiskowe podięcia pracy nad sobq stały się podstawa do dokonania analizy obszarów wychowawczych szkoły i wskazania na drzemiqce w nich możliwości.

Celem artykułu jest ukazanie roli wychowawcy/nauczyciela jako inspiratora i organizatora działalności samowychowawczej ucznia, rolę działalności organizacyinej szkoły, ze szczególnym wskazaniem na udział w niej uczniów, wyrażajqcej się w samorzqdności, na znaczqca rolę grupy oraz czasu godzin wychowawczych. Podstawa do
\end{abstract}

StOWA KLUCZOWE wychowanie, samowychowanie, szkoła, nauczyciel, uczeń

\section{KEYWORDS}

upbringing, self-upbringing, school, teacher, pupil

SPI Vol. 22, 2019/1

ISSN 2450-5358

e-ISSN 2450-5366

DOI: 10.12775/SPI.2019.1.004

Nadestano: 30.10 .2018

Zaakceptowano: 26.03.2019

Artykuły i rozprawy 
napisania artykułu stała się analiza literatury pedagogicznej dotyczqcej samowychowania oraz pedeutologii. Analizowana problematyka wskazująca powyższe obszary oddziaływań ukazuje aspekty zarówno teoretyczne jak i praktyczne tychże oddziaływań.

\section{ABSTRACT}

In the process of upbringing, a pupil becomes a form-teacher for himself/herself and undertakes the choice of their own concrete life path; undertaking self-reliant decisions and taking responsibility for them; molding the sense of their own value, knowing themselves; the acceptance and formation of the ideal of their own person and its realization. These acts of doing do not appear independently in the pupil's activity. The stage of implementation to self -upbringing is noticed at the mid-schooling age, meaning that the school is this space is where one should look to implement activities to the process of upbringing. The as yet insufficiently described environmental factors of undertaking the work upon the self have become the basis for making the analysis of the upbringing areas of school and indicating the possibilities hidden inside.

The purpose of the article is to show the role of the form-teacher/ teacher as an initiator and organizer of self-upbringing activity of the pupil, the role of organizing activity of school with particular indication at the pupils' participation in it that is to be reflected in the self-governance, the significant role of the group and time assigned for the upbringing hours. The basis for the article is the analysis of pedagogical literature on self-education and pedeutology. The analyzed issues indicating the above interaction areas show the theoretical as well as practical aspects of these interactions.

\section{Wrowadzenie}

Szkoła funkcjonująca jako podstawowa instytucja oświatowa w systemie edukacji ,zajmuje się kształceniem i wychowaniem dzieci, młodzieży i dorosłych, stosownie do przyjętych w danym społeczeństwie celów i zadań oraz koncepcji oświatowo-wychowaw-

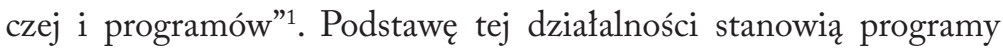

1 W. Okoń, Nowy stownik pedagogiczny, Warszawa 2001, s. 383. 
edukacyjne i program wychowawczy sformułowany i przyjęty przez placówkę. W świadomym wychowaniu szkolnym chodzi o to, aby ten wpływ był pozytywny i podporządkowany wszechstronnemu rozwojowi ucznia jako osoby. Każda osoba ludzka kształtuje się jednak nie tylko pod wpływem czynników zewnętrznych, ale także dzięki wysiłkom własnym, co oznacza, że prowadzony proces wychowania musi być nie tylko działaniem organizowanym przez instytucje (szkoła) czy osoby (wychowawca/nauczyciel), ale również działaniem, w którym sam wychowanek włącza własne siły i doskonali swoją osobowość

Wskazując na cele i zadania szkoły, nie można w nich pominąć pomocy uczniom w podejmowaniu pracy nad sobą. Samowychowanie, wyrażające się w dobrowolnej aktywności własnej zmierzającej do rozwoju własnej osoby, obejmuje zespół odpowiednio dobranych zabiegów takich, jak wyznaczanie sobie zadań, określenie norm i reguł działania, decydowanie o nich oraz podejmowanie się ich realizacji. Człowiek z własnej woli będzie decydował o użyciu odpowiednich wzorów, tworzył program działania, realizował go, ale te $\dot{z}$ kontrolował i oceniał przebieg i wyniki własnej pracy ${ }^{3}$.

Stawanie się dla siebie zarówno wychowankiem, jak i wychowawcą, nie jest procesem samoistnym, nie występuje w sposób mimowolny, lecz kształtuje się w wyniku oddziaływań osobowych i instytucjonalnych ${ }^{4}$. Podjęcie pracy nad sobą powinno zatem być poprzedzone etapem wdrażania do samowychowania. Według Andrzeja J. Sowińskiego etap ten obejmuje dwa zakresy oddziaływań: nabywanie przez wychowanka postaw interpersonalnych oraz inicjowanie, organizowanie i ukierunkowanie działań samowychowawczych wychowanka. Do nabywanych postaw zalicza on w pierwszym rzędzie: „postawę samokontroli, odpowiedzialności za siebie, osobistej odwagi i działalności, aby można było w dalszej kolejności kształtować postawę samodzielności, perfekcjonizmu oraz osobistej godności" ${ }^{5}$. Oddziaływania w tym zakresie mają na celu stałe mobilizowanie wychowanka, który nie powinien zadowalać się już osiągniętym poziomem

2 S. Pacek, Jak kierowaí samowychowaniem uczniów, Warszawa 1984, s. 16-17.

3 Por. I. Jundziłł, O samowychowaniu, Warszawa 1975, s. 94.

4 A.M. de Tchorzewski, Wstęp do teorii wychowania, Kraków 2016, s. 192.

5 A.J. Sowiński, Samowychowanie w interpretacji pedagogicznej, Szczecin 2006, s. 40. 
osobistego rozwoju i dlatego jego aktywność będzie przejawiać się w podejmowaniu coraz to nowych wyzwań i podnoszeniu wymagań wobec siebie. Drugi zakres oddziaływań wdrażania do samowychowania to zamierzone i planowe wprowadzanie wychowanka w nowe działania i techniki pracy nad sobą. Sowiński wskazuje na takie zadania szczegółowe, jak: „ukazywanie wzorców dążeń samowychowawczych, które mogą stanowić źródło inspiracji w budowaniu ideału własnej osoby; przyswajanie technik samowychowania efektywnie poszerzających samowiedzę; wprowadzenie w sytuacje wyzwalające pro społeczne motywy, które mogą inspirować działania samowychowawcze; przysposobienie do programowania i planowania pracy nad sobą; wdrażanie do prac i ćwiczeń związanych z realizacją konkretnych zadań perfekcjonistycznych oraz zapoznanie ze sposobami dokonywania samokontroli i samooceny"6.

Etapem wdrażania do samowychowania obejmuje się działania dostosowane do rozwoju psychofizycznego dzieci w średnim wieku szkolnym. Zatem jego zaistnienie będzie zależało od działań mających miejsce również w szkole. Stąd konieczna jest analiza różnych obszarów życia szkoły i drzemiących w ich obrębie możliwości oddziaływań samowychowawczych.

\section{Nauczyciel jako inspirator i organizator pracy samowychowawczej ucznia}

Pierwszym i najważniejszym obszarem wychowawczym szkoły, w którym należy poszukiwać elementów wdrażania do samowychowania, są odniesienia osobowe nauczyciela i ucznia. Niewątpliwie każdy nauczyciel wywiera określony wpływ na uczniów, wpływa na zachowanie, sposób myślenia, postawy, obyczaje uczniów, itp. Osobowość nauczyciela, jego styl wychowania i nauczania, umiejętności psychospołeczne, zwłaszcza umiejętność nawiązywania i utrzymywania kontaktów z poszczególnymi uczniami i całą grupą, będą decydowały o postrzeganiu go przez ucznia, ale też umożliwiały oddziaływanie na jego rozwój. Nauczyciel, aby uruchomić pracę samowychowawczą ucznia, powinien uruchamiać jego aktywność, czyli

6 Tamże. 
budzić zainteresowanie wychowanka pracą nad sobą, jego motywację do samodoskonalenia się, samokontrolę i samoocenę, pobudzać do samodzielnego zdobywania wiedzy o sobie ${ }^{7}$.

Zanim wychowawca zacznie zastanawiać się nad metodami pracy wychowawczej z klasą, powinien odpowiedzieć sobie na pytanie, jaki sam jest w stosunku do uczniów i klasy. Tu postawa najbardziej pożądaną będzie postawa partnerstwa, otwartości i dialogu. Partnerstwo polegające na współdecydowaniu i współodpowiedzialności, czyli umożliwianie uczniom wspólnego i samodzielnego podejmowania decyzji, zachęca ich do aktywności i samodzielności w różnego rodzaju działaniach praktycznych. Klasa, za którą decyzje są podejmowane i która nie czuje się odpowiedzialna za efekty zadań, $\mathrm{z}$ dużym prawdopodobieństwem będzie bierna, niezainteresowana, motywowana do aktywności przede wszystkim (jeśli nie wyłącznie) wzmocnieniami zewnętrznymi. Janusz Tarnowski wskazywał, że wychowanie należy zhumanizować poprzez unikanie ingerowania w życie wychowanka, a raczej poprzez uczestniczenie $\mathrm{w}$ nim jako przykład, wzór osobowościowy. Takie oddziaływanie ma doprowadzić ucznia do postawy dialogu ${ }^{8}$. Wychowanie dialogowe wymaga wspólnej płaszczyzny porozumienia, a potem nauczenia się słuchania i rozmowy. W rozmowie, która może stać się dialogiem, istnieje szansa na wzajemne odkrywanie siebie i nowych rzeczywistości. Jest to możliwe dzięki stawianiu pytań, wzajemnym słuchaniu i rozmowie, ale trzeba często przezwyciężyć lęk, usunąć uprzedzenia i znaleźć język porozumienia, który dla obu stron będzie znaczył to samo. Tu potrzebna jest otwartość, szczerość i autentyczność. W tej postawie dialogu ważna jest również akceptacja odrębności myśli wychowanka, szacunek dla niego i jego myślenia.

Należy zauważyć, że partnerstwo nie jest jednak równoznaczne z zajęciem postawy pełnego przyzwolenia na dowolną aktywność klasy, dlatego nauczyciel musi posiadać umiejętność egzekwowania obowiązującego systemu norm i zasad. Pogodzenie ze sobą tych dwóch opcji jest możliwe tylko wtedy, jeśli komunikacja między wychowawcą a uczniami jest otwarta. Między tymi dwoma krańcami

Tamże, s. 43.

8 Por. J. Tarnowski, Pedagogika dialogu, w: Edukacja alternatywna - dylematy teorii i praktyki, red. B. Sliwerski, Kraków 1992, s. 125-126. 
jest miejsce na podejmowanie wspólnych decyzji i dzielenie się odpowiedzialnością za nie ${ }^{9}$. Bardzo ważnym elementem postawy partnerskiej wychowawcy jest pozwolenie uczniowi na popełnianie błędów. Przeżycie porażki, która była wynikiem własnej decyzji, jest ważniejsze niż osiągnięcie sukcesu będącego konsekwencją podsuniętego czy nakazanego postępowania.

Rozpoczęcie przez ucznia pracy nad sobą zmienia zadania wychowawcy. $Z$ inicjatora ma się przekształcić w tego, który ciągłość tej działalności będzie podtrzymywał, zwłaszcza w jej początkowej fazie. Pomoże to zmniejszyć ryzyko pomyłki i błędu, wynikającego z niewłaściwych wyborów, a zwiększy korzyści wynikające ze znalezienia właściwej drogi. Ukierunkowywanie wysiłków samowychowawczych ucznia zapobiegnie działaniom przypadkowym i niesystematycznym $^{10}$. Skuteczność tych oddziaływań będzie zależeć od rozwagi i „delikatności” nauczyciela tak, aby nie zaburzyć samodzielności ucznia. Warunkiem będzie tu akceptowanie uczniów, czyli uznawanie ich takimi, jakimi są naprawdę, zgoda na ich osobowość, odrębność, niezależnie od tego, jacy są, czyli wykluczająca wszelkie uprzedzenia; rozumienie uczniów, czyli umiejętność wczuwania się w stany i procesy psychiczne uczniów, ale też autentyczność nauczyciela, czyli zgodność z samym sobą, szczerość i spontaniczność w zachowaniach.

\section{Działalność organizacyina szkoły, samorzq̨aność}

Szkoła bardzo wcześnie zaczyna być miejscem wypełniającym życie dzieci i młodzieży. Jest jedną z najstarszych instytucji społecznych, tworzonych w celu przygotowania młodego pokolenia do życia dorosłego ${ }^{11}$. Nabywając wiedzę o jej funkcjonowaniu, uczeń tworzy jej własny obraz, a co najważniejsze, postrzega siebie jako członka tej organizacji. Osoby spełniające swoje funkcje (od dyrektora szkoły po osoby sprzątające) i ich wzajemny stosunek do uczniów powinny tworzyć kulturę niewymuszonej współpracy, polegającej na wspólnym

9 Zob. J. Sempryk, Podmiotowoś i partnerstwo w wychowaniu, „Perspektiva. Legnickie Studia Teologiczno-Historyczne” 2006, R. 5, nr 2(9), s. 116-120.

10 S. Pacek, Jak kierować samowychowaniem uczniów, dz. cyt., s. 43-44.

11 I. Szybiak, Z dziejów szkoty, w: Sztuka nauczania, t. 2: Szkota, red. K. Konarzewski, Warszawa 1991, s. 9. 
ustalaniu celów i zadań pracy. Poza tym stosunki międzyludzkie w szkole powinny opierać się na wzajemnym zaufaniu. Podmioty szkoły razem budują swoją wspólnotę, wpływają na wizerunek tego miejsca, mają poczucie, że są członkami wyjątkowej grupy i zbiorowości. Zatem każdy z nauczycieli i innych pracowników szkoły powinien mieć świadomość wspólnotową oraz potrzebę budowania wspólnego systemu, a co za tym idzie budować samorządność i rozbudowywać kompetencje społeczne, dzieląc się swoim potencjałem ${ }^{12}$.

Nabywanie przez wychowanka postaw interpersonalnych powinno mieć miejsce „w naturalnych sytuacjach życia codziennego, wykonywanych przez niego czynnościach i zadaniach związanych ze spełnianiem roli ucznia i członka grupy rówieśniczej, w czasie wypełnionym obowiązkami szkolnymi i domowymi, a także w czasie wolnym"13. Szkoła, formułując podstawowe wzory wartości i przekonań, ma wpływ na ich przyjęcie i wyrażanie przez uczniów. Stanowienie i egzekwowanie w szkole prawa, którego wyrazem są: statut, regulaminy; utrzymanie dyscypliny szkolnej, organizacji pracy pracowników szkoły, jak i uczniów, utrzymanie porządku i dyscypliny, ma nie tylko porządkować przestrzeń funkcjonowania wychowanka. Włączając w ten sposób wychowanków w sposób świadomy w krąg stosunków społecznych, pokazujemy mu postawy wspólnotowe oraz kształtujemy umiejętności wzajemnego współżycia i współdziałania. Wszystko to, co ma miejsce w warunkach codziennych, naturalnych i odzwierciedla się w czynnościach i zadaniach, związanych ze spełnianiem roli ucznia, a tym samym jest powiązane $\mathrm{z}$ realiami życia codziennego, a nie problemami ideowymi.

Jednak ograniczenie wychowania do właściwej organizacji pracy może prowadzić do mnożenia kodeksów, regulaminów praw i obowiązków, bez potrzeby poczucia odpowiedzialności i obowiązkowości. Obroną przed takimi skutkami będzie przekazanie współodpowiedzialności za szkołę w ręce ucznia, czyli jego samorządnośćc ${ }^{14}$. Nie chodzi jednak tylko o samorządność zinstytucjonalizowaną, wyrażającą się w formach prawnych, takich jak samorząd klasowy czy

12 M. Sowisło, Funkcje samorzadu uczniowskiego: zatożenia i rzeczywistość, Kraków 1996, s. 43.

13 A.J. Sowiński, Samowychowanie w interpretacji pedagogicznej, dz. cyt., s. 40.

14 Zob. P. Ziółkowski, Samorzad uczniowski - idee, uwarunkowania, doświadczenia, Bydgoszcz 2014, s. 95-98. 
szkolny, ale o każdą samodzielną, spontanicznie podjętą, zorganizowaną działalność uczniów. Szczególnie cenne są te inicjatywy, które leżą na granicy możliwości uczniów, angażują ich w pełni, zmuszają do wysiłku intelektualnego, a także te, które oddziałują szeroko na środowisko, mobilizując również podmioty pozaszkolne. Ważną rolę wychowawczą odgrywa efekt końcowy samodzielnych działań, którym jest satysfakcja $\mathrm{z}$ dobrze wykonanego dzieła i radość $\mathrm{z}$ sukcesu ${ }^{15}$. To ona będzie budzić motywację do podejmowania coraz to nowych wyzwań, a co za tym idzie rozwijania aktywności ucznia.

Samorządność jest niezbędnym czynnikiem dojrzewania do podejmowania społecznej odpowiedzialności oraz do samowychowania. Staje się okazją wyzwalającą prospołeczne motywy, a kształtowanie dzięki niej całej palety postaw może wywołać chęć doskonalenia się, czyli podniesienia na wyższy poziom swojej wiedzy, umiejętności i kompetencji. Może to stanowić nie tylko poszukiwanie ideału swojej osoby, ale też inspirować działania samowychowawcze.

\section{Wzajemne oddziaływania w grupie rówieśniczej}

Decydującym czynnikiem kształtowania osobowości wychowanka jest układ stosunków wewnętrznych oraz organizacja życia zespołu. W każdej grupie obowiązuje pewien zespół norm postępowania, na którego straży stoi tak zwana kontrola społeczna, polegająca na bezpośrednim reagowaniu ogółu na zachowania poszczególnych jednostek i nagradzaniu w ten sposób zachowań pożądanych, a karaniu niepożądanych. Życie w grupie opiera się na jednoczesnym przewodnictwie i podporządkowaniu każdego członka w stosunku do każdego innego oraz odpowiedzialności jednostek przed pozostałymi. W grupie można zaspokoić wiele potrzeb, jak: potrzebę bezpieczeństwa, kontaktu emocjonalnego, akceptacji przez grupę, uznania i szacunku, potrzebę sukcesu, ale też wykształcić wiele postaw interpersonalnych ${ }^{16}$. Nauczyciel musi zdać sobie sprawę, że na niepowodzenie skazana jest próba zmiany ucznia poza klasą, czyli poza jego grupą

15 Ministerstwo Edukacji Narodowej, O programie wychowawczym szkoty. Biblioteczka Reformy, Warszawa 2001, s. 22.

16 I. Ramik-Mażewska, Klasa szkolna jako przestrzeń innego, „Studia Edukacyjne" 2015, nr 34, s. 92-93. 
odniesienia oraz bez uwzględniania norm i wartości obowiązujących w klasie ${ }^{17}$.

Klasa jest grupą zadaniową powołaną do realizacji postawionych przed nią celów. $Z$ tego punktu widzenia nauczyciele i uczniowie tworzą wspólnie zespół zadaniowy i wspólnie odpowiadają za efektywność wykonywanej pracy. Wyzwolenie zaangażowania uczniów i podzielenie się przez nauczyciela odpowiedzialnością za proces i efekt pracy zmienia nie tylko motywację zespołu, ale także relację grupy z nauczycielem. Mimo że dalej będzie on spełniał rolę kierowniczą, to zacznie być postrzegany i traktowany jako pełnoprawny, a nawet niezbędny członek zespołu. Podstawowym zadaniem wychowawcy w pracy z zespołem jest zorganizowanie jego życia i działalności. Wychowawca musi zatroszczyć się o obranie wraz z zespołem wspólnych celów działania oraz norm, które regulują zachowanie się jednostki wobec innych członków grupy, jak również wobec osób z zewnątrz, niebędących członkami grupy. Aby praca z grupą klasową stanowiła element wdrażający wychowanków do pracy nad sobą, należy włączyć zespół wychowanków do udziału w podejmowaniu różnych decyzji oraz wyzwalać i w pełni wykorzystywać wszelkie inicjatywy zespołu. Służy temu inicjowanie aktywności zadaniowej, inicjowanie dyskusji wymagającej podjęcia decyzji grupowej czy praca nad przyjęciem współodpowiedzialności wychowanków. „Jeśli chcemy nie zmarnować możliwości samowychowawczych uczniów, przestańmy za nich decydować, za nich pracować, za nich ponosić odpowiedzialność. Twórzmy warunki, aby oni sami mogli wspólnie decydować, współpracować, ponosić odpowiedzialność za to, co ich dotyczy i za to, co od ich zachowania i działania zależy"18.

Umiejętność wzajemnego porozumiewania się w grupie ma być inicjowana przez nauczyciela. Wymaga to spełnienia pewnych warunków, takich jak odpowiednia postawa nauczyciela, dbałość o właściwe zadawanie pytań, unikanie udzielania rad i powinno przyjąć formę rozmowy kierowanej lub niekierowanej oraz dyskusji. Dyskusja umożliwia klasie ujawnienie rzeczywistych postaw wobec sprawy oraz otwarte ustosunkowanie się do propozycji rozwiązania problemu. Grupa, mając poczucie współautorstwa, z dużo większym

M. Łobocki, Teoria wychowania w zarysie, Kraków 2004, s. 325-327.

18

S. Pacek, Jakkierowaí samowychowaniem uczniów, dz. cyt., s. 44. 
prawdopodobieństwem przyjmie ją za swoją ${ }^{19}$. Wydaje się zatem koniecznością stosowanie takich technik wychowania, jak na przykład burza mózgów, decyzja grupowa czy socjodrama lub gry dramatyczne. Techniki te sprawiają, że ważne decyzje, dotyczące reguł obowiązujących w społeczności, podejmowane są wspólnie, poprzez uzyskanie akceptacji wszystkich, na drodze negocjacji i z możliwością przeformułowania proponowanych reguł. Wzmacniając komunikację między grupą a wychowawcą, umożliwiają wzięcie współodpowiedzialności za wypracowane rozwiązanie. Otwarta dyskusja i konfrontacja postaw mają także walor zwiększenia wglądu społeczności w związek między przyjętymi rozwiązaniami a interesami poszczególnych osób i klasy jako całości ${ }^{20}$.

Nauka współpracy i współdziałania ma się przejawiać w racjonalnym organizowaniu działań uczniów. Chodzi o taki podział zadań, aby nauczyć wychowanków działań w sposób indywidualny, zespołowy i zbiorowy. Uczniowie mają dostrzegać, że podejmowanie przez nich działań świadomych i celowych oraz wykonywanie ich w taki sposób, aby stanowiły pewną strukturalną całość, będzie przyczyniało się do osiągnięcia postawionego celu, ale również dostrzegają sensowność podejmowanych przez nich działań. Racjonalne organizowanie działań uczniów wymaga od nauczyciela nie tylko pogłębionej refleksji pedagogicznej, ale przede wszystkim wspólnego z uczniami planowania, umiejętności określenia celu i ustalenia warunków i środków; wymaga sporządzenia dokładnego planu, podziału zadań na zasadzie dobrowolności oraz dyskretnej kontroli, która powinna stanowić raczej samokontrolę i samoocenę. Zwłaszcza ten ostatni etap będzie bardzo istotny, gdyż ma wykształcić umiejętność oceniania siebie $\mathrm{i}$ innych ${ }^{21}$.

19 J. Kosz, Wspótdziatanie w szkole - oczekiwanie i potrzeba wspótczesnej praktyki edukacyjnej, „Forum Dydaktyczne” 2009, nr 5-6, s. 113. 


\section{Czas godzin wychowawczych}

Zamierzone i planowe wprowadzanie wychowanka $\mathrm{w}$ proces samowychowania będzie ukazywaniem mu i wdrażaniem go do konkretnych czynności oraz zapoznaniem z metodami pracy nad sobą. Czynności te wynikają z kolejnych etapów procesu samowychowania, takich jak: idealizacja, samopoznanie, samoocena wstępna, aspiracje perfekcjonistyczne, decyzje samorealizacyjne, działania samowychowawcze i samoocena końcowa ${ }^{22}$.

Wychowanie, podejmowane świadomie lub realizowane nieświadomie, odbywa się na wszystkich zajęciach, jednak koncentracja na realizacji programu sprawia, że może nie starczać czasu na osobowy rozwój człowieka. Dlatego tak istotnym dla wdrażania uczniów do samowychowania będzie czas godzin do dyspozycji wychowawcy klasy, czyli godzin wychowawczych. Ta godzina ma zatem być wykorzystana maksymalnie, w sposób zaplanowany, celowy i przemyślany w obszarze wychowania młodego człowieka. W założeniu ta jedna godzina w tygodniu ma być poświęcona sprawom wychowawczym. $Z$ rozmów z uczniami wynika, że nauczyciele skupiają się raczej na czynnościach formalnych, takich jak usprawiedliwienia nieobecności, analiza ocen, organizowanie pracy klasy, przygotowanie akademii, obchodów świąt, dekoracji itp. Poświęcenie godzin wychowawczych wyłącznie sprawom bieżącym (nawet wychowawczo istotnym) sprawia, że wychowanie postrzegane jest raczej jako reagowanie nauczyciela na złe zachowania uczniów, dyscyplinowanie ich albo te $\dot{z}$ kojarzone jest $\mathrm{z}$ organizowanie życia klasy. Jest to więc bardziej godzina organizacyjna $\mathrm{z}$ wychowawcą niż godzina wychowawcza, a co za tym idzie wychowawca nie jest wychowawcą, a jedynie nauczycielem-organizatorem.

Już sam wybór tematów poruszanych w czasie godzin będących do dyspozycji wychowawcy klasy wymaga namysłu. Oś tematyczną godzin wychowawczych muszą stanowić programy wychowawcze szkoły, ale szczegółowy wybór należy do wychowawcy. Czas godzin wychowawczych powinien być poświęcony na naukę umiejętności odczytywania świata i siebie samego w tym świecie. Praca nad sobą bardzo często rozpoczyna się od poznania samego siebie, będącego

22 Por. A.M. de Tchorzewski, Wstęp do teorii wychowania, dz. cyt., s. 190-191. 
gromadzeniem informacji o swoich właściwościach fizycznych i psychicznych za pomocą obserwacji własnego zachowania, analizy własnych reakcji, ale też na podstawie opinii innych ${ }^{23}$. Godzina wychowawcza jest najlepszym czasem do zapoznania ucznia $\mathrm{z}$ metodami i narzędziami poznania siebie. Pomoc wychowawcy powinna wyrażać się też zachętą do refleksji nad własnymi osiągnięciami, zainteresowaniami, motywacją itp. ${ }^{24}$.

Życie w pluralistycznym społeczeństwie, które zmusza do konkurencyjności i daje bogatą ofertę różnych zachowań i wartości, jest dla młodego człowieka bez doświadczenia niezwykle trudne. Konieczna zatem jest wielotematyczność godzin wychowawczych, która ma odpowiadać gamie problemów życiowych, które nurtują uczniów oraz dylematów przed którymi stoją ${ }^{25}$. Należy zaznaczyć, że wybór tematów powinien należeć zarówno do wychowawcy, jak i do ucznia, bo tylko on ujawnić może tematykę najbardziej dla niego aktualną i potrzebną.

Godzina wychowawcza, aby spełniła zadanie wdrażania do samowychowania, wymaga także specyficznych metod oraz warunków pracy. Każdy zespól jest inny, każdy ma inne potrzeby, zatem wychowawca musi sam dorobić się warsztatu pracy, do którego powinny należeć metody aktywizujące uczniów, pozwalające wcielać się w różne role, przeżywać różnorodne sytuacje, odczuwać i nazywać emocje oraz radzić sobie $z$ nimi, jak również problemowe, pozwalające na poszukiwanie motywów działania i sposobów rozwiązań. Metody te uaktywniają wychowanka do szukania przyczyn i rozwiązań, pozwalają na analizę problematyki, a także zmuszają do podejmowania decyzji i przyjęcia związanej z nią odpowiedzialności. Dużą rolę będą tu odgrywać wychowawcze metody oddziaływań grupowych, które dodatkowo postawią wychowanka $w$ konfrontacji z innymi i ich sposobem myślenia ${ }^{26}$.

Z. Matulka, Samowychowanie chrześijańskie, Torun 1995, s. 44.

Por. K. Ekert, Jak pracować z mtodzieżq na lekcjach wychowawczych, Wrocław 2015, s. 9.

25 Ministerstwo Edukacji Narodowej, O programie wychowawczym szkoty. Biblioteczka Reformy, Warszawa 2001, s. 23.

Zob. M. Łobocki, Teoria wychowania w zarysie, Kraków 2004, s. 218-225, 234-235, 243-250. 
Stosowanie takich metod dobrze jest wzmocnić zapewnieniem odpowiednich warunków zewnętrznych, takich jak odnowiona sala z miejscami np. do odegrania scenek, ustawiony krąg krzeseł itp. Nie tylko zburzy to barierę między wychowawcą a wychowankami, ale też w naturalny sposób otworzy uczestników na wzajemna wymianę myśli i spostrzeżeń. 45-minutowe spotkanie ma być czasem spędzonym w sposób atrakcyjny, ale przede wszystkim wartościowy.

\section{Zakończenie}

Przyjęcie prawdy, że młody człowiek jest istotą rozumną i wolną, wrażliwą na dobro, prawdę i piękno, zdolną do samoświadomości, samorealizacji i twórczej aktywności, ale również transcendencji, stoi u podstaw wszelkich działań wspomagających podjęcie trudu pracy nad sobą. Zapewnia to wychowankom prawo do bycia samodzielnymi i niezależnymi, ale też do ponoszenia odpowiedzialności za swoje postępowanie i kierowanie własnym rozwojem. $\mathrm{Za}$ to niezbywalne prawo do pełnego rozwoju osobowości odpowiedzialność ponosi również szkoła, której podmioty muszą uświadomić sobie, że wdrażanie do samowychowania jest jednym $z$ istotnych dla nich zadań. Jeśli to nie nastąpi, prawdziwa będzie krytyka Stefana Packa, według którego „szkoła wykorzystuje zaledwie cześć potencji i możliwości ucznia. (...) Wychowankowie w czasie pobytu w szkole nie mają dostatecznie dużo okazji do włączania własnych sił autoregulacyjnych dla dokonywania przekształceń i doskonalenia swojej osobowości. Nie mogą dokonywać wyboru konkretnej, własnej drogi życiowej, podejmować samodzielnych decyzji i przyjmować za nie odpowiedzialności, nie dysponują okazją do kształtowania poczucia własnej wartości, poznania siebie, akceptowania, formowania ideału własnej osoby i jego realizowania. Kontrola z zewnętrz, przy której wychowankowie są przede wszystkim obiektem manipulacji, nie ułatwia im tym samym osiągania dojrzałości do samowychowania"27.

27 S. Pacek, Jak kierować samowychowaniem uczniów, dz. cyt., s. 16-17. 


\section{Bibliografia}

Ekert K., Jak pracowaí z mtodzieżq na lekcjach wychowawczych, Instytut Edukacji Społecznej, Wrocław 2015.

Jundziłł I., O samowychowaniu, Nasza Księgarnia, Warszawa 1975.

Kosz J., Wspótdziatanie w szkole - oczekiwanie i potrzeba wspótczesnej praktyki edukacyjnej, „Forum Dydaktyczne” 2009, nr 5-6, s. 107-118.

Łobocki M., Teoria wychowania w zarysie, Oficyna Wydawnicza „Impuls”, Kraków 2004.

Matulka Z., Samowychowanie chrześcijanskie, Wydawnictwo Adam Marszałek, Toruń 1995.

Ministerstwo Edukacji Narodowej, O programie wychowawczym szkoty, Biblioteczka Reformy, Warszawa 2001.

Okoń W., Nowy stownik pedagogiczny, Wydawnictwo Akademickie "Żak”, Warszawa 2001.

Pacek S., Jak kierować samowychowaniem uczniów, WSiP, Warszawa 1984.

Pietrasiński Z., Kierowanie wtasnym rozwojem, Iskry, Warszawa 1977.

Ramik-Mażewska I., Klasa szkolna jako przestrzeń innego, „Studia Edukacyjne" 2015, nr 34, s. 89-100.

Sempryk J., Podmiotowośc i partnerstwo w wychorwaniu, „Perspektiva. Legnickie Studia Teologiczno-Historyczne” 2006, R. 5, nr 2(9), s. 109-121.

Sowiński A.J., Samowychowanie w interpretacji pedagogicznej, Oficyna IN PLUS, Szczecin 2006.

Sowisło M., Funkcje samorzadu uczniowskiego: zatożenia i rzeczywistość, WSP, Kraków 1996.

Szybiak I., Z dziejów szkoty, w: Sztuka nauczania, t. 2: Szkota, red. K. Konarzewski, Wydawnictwo Naukowe PWN, Warszawa 1991.

Tarnowski J., Pedagogika dialogu, w: Edukacja alternatywna - dylematy teorii i praktyki, red. B. Śliwerski, Oficyna Wydawnicza „Impuls”, Kraków 1992.

Tchorzewski A.M. de, Wstep do teorii wychowania, Akademia Ignatianum w Krakowie Wydawnictwo WAM, Kraków 2016.

Ziółkowski P., Samorzad uczniowski - idee, uwarunkowania, doświadczenia, Wydawnictwo Uczelniane Wyższej Szkoły Gospodarki, Bydgoszcz 2014.

\section{ADRES DO KORESPONDENCJI}

Dr Ewa Miśkowiec

Akademia Ignatianum w Krakowie

Wydział Pedagogiczny

Instytut Nauk o Wychowaniu

e-mail: ewa.miskowiec@ignatianum.edu.pl 